\title{
Litiasis ureteral gigante
}

González Sala JL, Hannaoui Hadi N, Peña González JA, Prats López J, Abad Gairin C, García D.

\section{Servicio de Urología. Corporació Sanitaria Parc Taulí. Sabadell. Barcelona.}

Actas Urol Esp. 2008;32(2):269

W $\begin{aligned} & \text { ujer de } 55 \text { años que nos es remitida por dolor } \\ & \text { lumbar derecho de larga evolución. }\end{aligned}$

En la Rx simple se aprecia gran litiasis ureteral D (10cm longitud) a modo de "molde" ureteral (Fig. 1). La UIV confirma dicha litiasis con afectación funcional y extremo distal "enclavado" en cruce de las iliacas (Fig. 2).

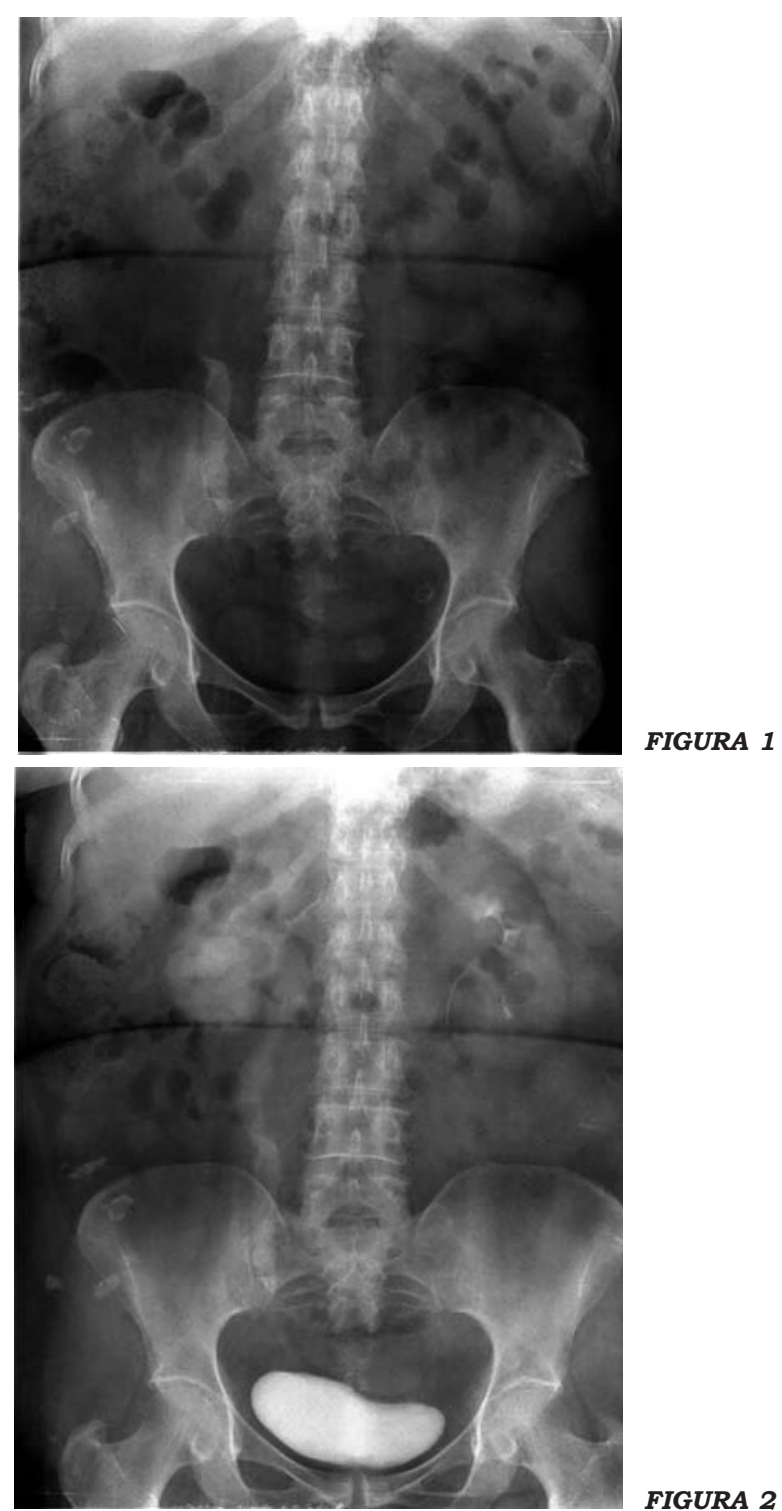

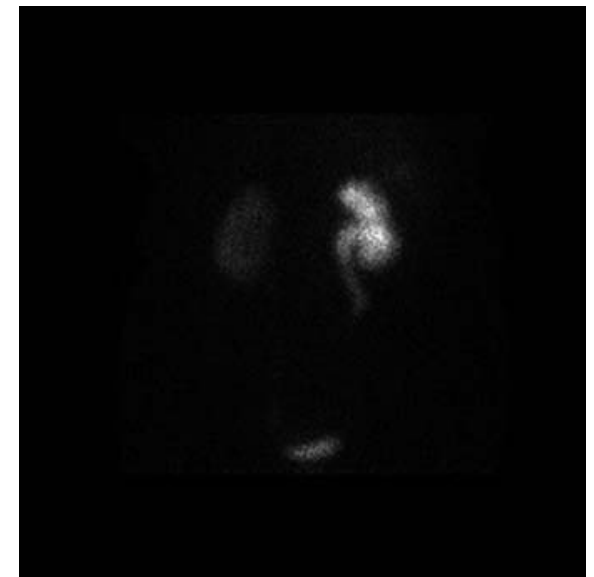

FIGURA 3

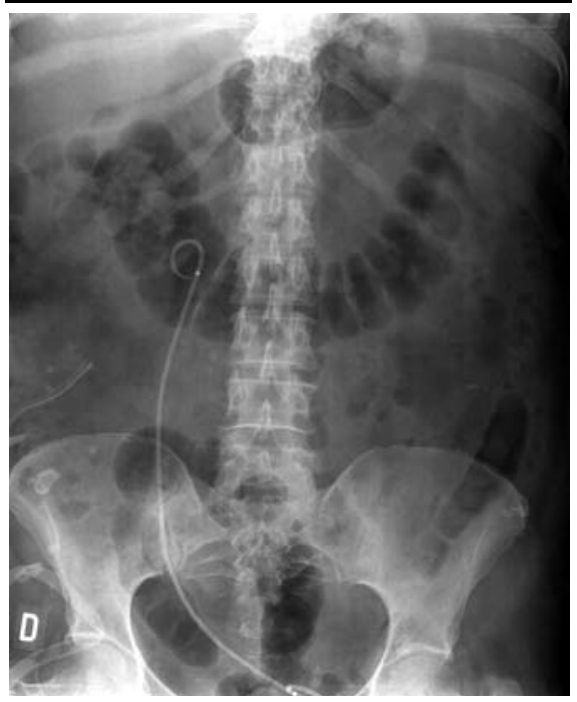

FIGURA 4

Por la edad de la paciente, la clínica de dolor lumbar continuo y el informe renográfico (respuesta a diurético y aportación del 30\% a la función renal global) (Fig. 3), se decide tratamiento quirúrgico conservador mediante Ureterolitotomía clásica y colocación de catéter ureteral Doble "J" con Rx control que muestra ausencia de restos litiásicos (Fig. 4).

Correspondencia autor: Dr. J.L. González Sala

Servicio de Urología. Corporació Sanitaria Parc Taulí

Parc Taulí, s/n 08208-Sabadell (Barcelona) Tel.: 937231010

E-mail: jlsales@mixmail.com

Información artículo: Imágenes en Urología

Trabajo recibido: octubre 2006

Trabajo aceptado: noviembre 2006 